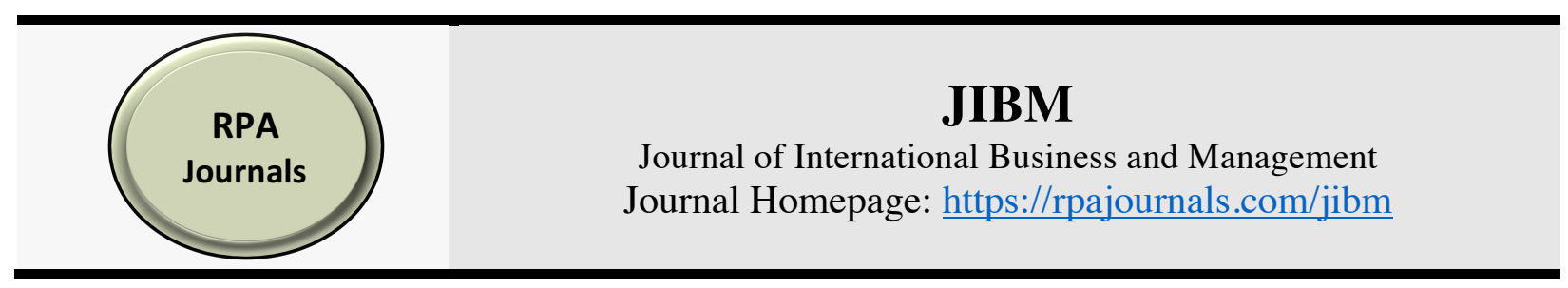

\title{
Firm Level Factors and Organization Performance: the Moderating Role of Industry Environment
}

\author{
Paul Kariuki" \\ Reuben $\mathrm{Nguyo}^{2}$ \\ Jomo Kenyatta University Of Agriculture And Technology (JKUAT), Kenya' \\ Taita Taveta University (TTU), Kenya ${ }^{2}$
}

\begin{abstract}
The purpose of this paper was to determine the Moderating role of Industry environment on relationship between Firm Level Factors (Organization resources, culture and structure) and performance of large manufacturing firms in Kenya. Questionnaires were issued to 102 Chief Executive Officers of large manufacturing firms in Kenya and 94 responded. One hypothesis was established through literature review. The results show that industry environment has statistically significant moderating effect on combined effect of Organization structure, culture, resources on performance. The performance was measured based on return of assets, internal processes and customer perspective. These findings contribute to resource-based theory by complementing and extending earlier research on the role of industry environment on firm level factors relationship with performance.
\end{abstract}

Keywords: Organizational resources, Culture, Structure, Manufacturing firms, Performance, Industry environment

*Corresponding author: Paul Kariuki; Email: paulmuturikariuki@gmail.com

DOI: https://doi.org/10.37227/jibm-2019-04-127

\section{Introduction}

Firm level factors are internal aspects in the organization. In this study the firm level factors studied are organization resources, culture and structure. Firm level factors are critical in determining organization performance. In literature there is school of thought that firm characteristics influence performance more than industry factors while industry organization theorists argue that industry factors matter most. Firm level factors play a major role but the industry context (environment) is likely to moderate the relationship with organization performance. The relationship between firm level factors and performance is unlikely to be direct.

Organizational resources are the various intangible and tangible assets an organization owns or controls (Grewal and Tansuhaj, 2001). Organizational culture describes the psychology, attitudes, experiences, beliefs, and values (personal and cultural values) of an organization (Schein, 2009). Organizational structure is described as the way responsibility and power are allocated and work procedures are carried out among organizational members (Robins and Decenzo, 2005). Industry environment is the overall economic, regulatory, social and political conditions that affect all participants in an industrial market. Studies have been done relating resources, culture, structure and 
performance. According to Crook et al, 2014 resources are related to performance. According to Eisend, Evanschitzky and Gilliland (2016) culture influences performance. Oyewobi, et al., (2013), found that organization structure had no direct impact on both financial and non-financial performance, while Jung and Kim, (2014) study in the USA showed that organizational structure affects perceived organizational performance. These studies have mainly studied independent and direct influence of resources, culture and structure on performance. Karabay \& Bergren (2013) study, based on 1000 largest manufacturing firms in Turkey found that firm related factors do not significantly influence performance. Efendiogm and Karabulut (2010) did not observe any significant relation between firm level factors and performance while Chen (2010) showed that firm factors explain a substantial part of Korean and Taiwanne firm performance. This indicate some contradictions of findings. Is the Industry environment factors the missing link?

Besides the conceptual gaps, there are contextual factors. Kenya Manufacturing sector is facing decelerated growth which indicates issues relating to performance. The sector recorded a decelerated growth of 3.5 percent in 2016 from a revised growth of 3.6 percent in 2015 . The sector's growth remained stifled in the period under review mainly attributable to the underperformance of other sectors such as agriculture and electricity that provide inputs for manufacturing activities. The near stagnation in the growth of manufacturing was also manifest in the slow uptake of credit from KSh 290.1 billion in 2015 to KSh 276.7 billion in 2016 (Kenya National Bureau of Statistics (KNBS), 2017). Despite the challenges facing the Kenya manufacturing sector, the government consider it to be key in achieving Kenya Vision 2030. To catalyze the growth and performance in the manufacturing sector in year 2018 the Kenyan Government made it to be among the Big Four Agenda.

This study sought to address the gaps/conflict in literature by studying the moderating role of industry environment. The research involved the study of combined effect of organization resources, culture and structure on organization performance. Each independent factor is unlikely to influence performance since is about the firm strategic architecture. The industry environment is likely to be a key determinant as to whether the firm level factors will positively have an effect on performance or not. Therefore, this study sought to determine is there a moderating role of industry environment on the relationship between firm level factors and organization performance? This study contributes to the strategic management literature that Industry environment has a moderating role on relationship of firm level factors and performance.

\section{Literature Review}

This study was anchored on Resources Based Theory. The resource-based view of the firm predicts that certain types of resources owned and controlled by firms have the potential and promise to generate competitive advantage, which eventually leads to superior organizational performance (Wernerfelt, 1984; 1995; Dierickx \& Cool, 1989; Barney, 1991; 1995; 2001a; 2001b; Peteraf, 1993; Chaharbaghi \& Lynch, 1999; Fahy, 2000; Priem \& Butler, 2001a; 2001b; Miller \& Ross, 2003; Morgan et al., 2004; King, 2007; Sirmon et al., 2007; Ainuddin et al., 2007). Resource-based theory (RBT) has emerged as a very popular theoretical perspective for explaining performance (Newbert, 2007). RBT assumes that resources are heterogeneously distributed among organizations and that many resources are not perfectly imitable or substitutable (Barney, 1991). Resource heterogeneity is a condition wherein organizations possess different bundles of resources (Peteraf, 1993).

\section{Organizational Resources}

Firm's resources have been classified into six strategic resources that are physical, reputational, organizational, financial, human intelligence, and technological (Barney, 1991). The key dimension of differences in strategies and performance levels among competitors within an industry is the existence of unique firm characteristics capable of producing core resources that are difficult to imitate (Wernerfelt, 1984; Barney, 1986; Peteraf, 1993). According to Wernerfelt (1984), firms possessing valuable, rare resources and capabilities would attain a competitive advantage, which 
would, in turn, improve their performance. Newbert (2007) categorized theoretical approaches based on RBT into four types of a resource; heterogeneity, organizing approach, conceptual-level, and dynamic capabilities. To achieve a superior competitive advantage, Besanko, et al., (2003) argue that a firm must create more values, which depends on its stock of resources and distinctive capabilities of using those resources. A firm must ensure its successful strategies and the created competitive strategies are sustainable for long-term profitability (Cullen and Parboteeah, 2005).

Peteraf (1993) suggested that a firm can sustain its competitive advantage if it is able to generate sustainable economic rent by endowing it with superior internal resources. To facilitate the sustainability of the economic rent for the firm in the long term, the superior resources of the firm must be inelastic in supply (Dierickx and Cool, 1989; Peteraf, 1993), inimitable or non-substitutable (Lippman and Rumelt, 1982; Porter, 1980; Rumelt, 1984) and the costs of the resources must be lower than their economic rents (Barney, 1986; Dierickx and Cool, 1989). Resources have generally been defined as those assets owned or controlled by a firm. According to Wernerfelt (1984), a firm's resources are those tangible and intangible assets tied semi-permanently to the firm". Building on the work of evolutionary economics the RBT has re-established the importance of an individual firm, as opposed to an industry as the critical unit of analysis. The RBT sees the firm as a bundle of resources (Barney, 1991; Wernerfelt, 1984).

According to Hoopes, Madsen, and Walker, (2003), since strategic resources generate economic value, an organization that possesses them can develop competitive advantages, and because strategic resources cannot be easily replicated, resources-based advantages can be sustained over time. Based on data from over 29,000 firms contained within 125 studies, Crook et al, 2014 results show that, on average, resources identified by researchers as strategic are related to performance. According to Alimin, Raduan, Jegak, and Haslinda (2012), organizational resources are the foundation for attaining and sustaining competitive advantage, which in turn leads to superior performance. Alimin et al., 2012 cross-sectional research conducted among manufacturers listed in the 2008 Federation of Malaysian Manufacturers Directory, showed that organizational resources were not significantly associated with competitive advantage. According to Alimin Ismadi Ismail et al (2012), conceptually and empirically, resources are the foundation for attaining and sustaining competitive advantage and eventually superior organizational performance.

Galbreath and Galvin (2008) demonstrated that firms' resources were more important than industry. In the study of 72 Spanish manufacturing firm, Lopez (2003) found empirically a significant relationship between a group of intangible resources (company reputation, human capital, and organizational culture) and organizational performance. The empirical results of the regression coefficients analysis indicated that intangible resources were positively related to the firm's performance. Carmeli and Tishler (2004) examined 99 local government authorities in Israel for the relationships of a set of intangible resources with a set of multi-performance measures (financial performance, municipal development, internal migration, and employment rate). The results from the multiple regression analysis indicated that all intangible resources variables were positively and significantly related to organizational performance variables. According to Anderson (2011), there is a positive relationship between resources and the performance of a firm. Unique resources of a firm lead to superior performance (Hoq and Chauhan, 2011). Tuan and Takahashi (2012) study on resources, organizational capabilities, and performance of manufacturing firms in Vietnam, found that different group of resources is related to each organizational capability and that cost reduction and quality capabilities are related to performance. This study focused on the following resources; Non-current assets, human capital, managerial capabilities, organizational reputation, labor relations, control of specific equipment, product procedural knowledge and patent.

\section{Organizational Culture}

Organizational culture refers to the underlying values, beliefs, and principles that serve as a foundation for the organization's management system as well as the set of management practices and behaviors that both exemplify and reinforce those basic principles (Denison, 1990). Practitioners and academics suggested that the performance of an organization is dependent on the values of the 
culture. Denison (1990) organizational culture model was based on four cultural traits; involvement, consistency, adaptability, and mission that had been shown in the literature to have an influence on organizational performance (Denison, 1990). Studies show that the relationship between many cultural attributes and high performance has not been consistent over time (Denison, 1990). Denison (1984) used data from 34 American firms on cultural performance over a period of five years and scrutinized the characteristics of organizational culture and tracked the performance over time in these firms. Denison (1984) found that organizations that have participative corporate cultures and well-organized workplaces had a better performance record than those that did not. The traits of organizational culture in Denison's framework was that effective organizations empower their people, build their organizations around teams, and develop human capability at all levels. According to Kopelman, Brief, \& Guzzo, 1990, organizational culture and performance are related even though the evidence regarding the exact nature of this relationship is mixed.

The literature distinguishes between four types of organizational cultures (Desphandé and Farley, 2004; Desphandé et al., 1993; Hartnell, Ou, and Kinicki, 2011): market, adhocracy, clan, and hierarchy. Desphandé and Farley (2004) have summarized the results of several studies and suggested a market $>$ adhocracy $>$ clan $>$ hierarchy ordering in the impact on firm performance. Gordon and DiTomaso (1992); Denison (1990), Kotter and Heskett (1992) and Lee (2006), found inconsistent results on the link between culture strengths and organizational performance. Companies with participative culture had a (Return on Assets) ROI that averaged nearly twice as high as those in firms with less efficient cultures.

Henderson and Cockburn (1994), Carmeli and Tishler (2004), studies of local government authorities in Israel identified that organizational culture and perceived organizational reputation were the two most significant variables relating to organizational performance in the Israel government authorities. Cameron and Quinn (2005), emphasize that the success of organizations is not only determined by external conditions but concluded that the remarkable and sustained success of some US companies "has had less to do with market forces than with company values" (Cameron and Quinn, 2005, p. 4). According to Romualdas and Vida (2006), organizational culture is a multidimensional phenomenon, which influences enterprise success (outcomes). According to Kraaijenbrink, Spender, and Green (2010) for a culture to generate superior performance, then it ought to be valuable, rare and hard to copy. Organizational culture has the potential to enhance organizational performance, employee job satisfaction, and the sense of certainty about problemsolving (Kotter, 2012).

Fazli and Alishahi (2012) study found that culture, strategy and knowledge management had a positive influence on performance. Organizational culture and human capital have a strong relationship with a firm's performance (Yazdani and Marva, 2013). One of the major reasons for the widespread popularity and interest in organization culture stems from the argument (or assumption) that certain organizational cultures lead to superior organizational financial performance. Olanipekun, et al., (2013) study on quantity surveying firms in Nigeria found that organization culture influenced performance. According to Eisend, Evanschitzky and Gilliland (2016) organizational culture type make a difference when it comes to performance outcomes. This study focused on the following culture dimensions; Equity, people orientation, innovativeness, high performance expectation, adaptability, involvement, employees' commitment.

\section{Organization Structure}

Chandler (1962) substantiated 'structure follows strategy' thesis based on four case studies of American conglomerates that dominated their industry from the 1920's onward. The ensuing debate on the contingent relationship between strategy, structure, and firm performance flourished in the 1970s and 1980s. Mintzberg (1979) indicated that an organic structure, with its low degree of formality and a high degree of information sharing and decentralization, improves an organization's flexibility and ability to adapt to continual environment change. According to According to Lenz (1980) organization structure has a 
direct effect on the success of an organized operation strategy. Lenz (1980) supports the argument that organizational structure shapes performance.

Many scholars have contended that structure matters for organizational performance as well as for the organization members' perceptions, actions and individual performance (Child, 1972; Hall, 1977; Dalton et al., 1980; O'Toole and Meier, 1999).Researchers have used ground-breaking work by Chandler to build the Strategy-Structure Performance (SSP) paradigm, which has become the most important substream of research on structural contingency theory (Galunic and Eisenhardt, 1994). Rather than seeing each strategy or structure alone having an important impact on performance, the paradigm holds that it is the linkage between them that is important (Lenz, 1980; Miller, 1988). Grewal and Tansuhaj (2001) reported that more successful companies had well defined organizational structures in sharp contrast to less successful companies. Focusing on large firms (Ekpu, 2004) found a positive relationship between the unstructured organizational patterns and large firm financial performance. Bucic and Gudergan (2004) defines the organizational structure as the formal system of task and reporting relationships that control, coordinates and motivates employees so that they cooperate to achieve organizational goals. According to Bucic and Gudergan (2004), there are four generic types of control mechanism which include centralization, formalization, outputs, and cloning. Robbin and DeCenzo (2005) argue that the organizational structure performs a significant role in the achievement of the organization's set objectives and accomplishment of its strategic goals and direction. The belief "one cap fits all" is non-existence in an organizational structure design as no two firms are entirely similar and as such faces different challenges from its environment. Lavie (2006) gave evidence that the level of organizational structure and strategies was positively related to company effectiveness. According to Chen and Huang (2006) decentralized and informal structure will lead to higher performance. Germain et al., (2006) studied the effect of structure on the performance mediating supply chain management and found that in a stable environment, the formal structure has a positive effect on the performance while in dynamic atmosphere negative effect is attained.

Wasserman (2008) used integrating inductive methods with the quantitative analysis of a unique panel of data set of 317 professional service firms. The researcher found that coordination challenges in these firm drive internal structures and the degree of strategy-structure fit have important performance implications for those firms. Zheng, et al., (2010) study observed a negative effect of structure on organizational effectiveness. According to Akinyele (2011), the organizational structure and strategies adopted by oil and gas marketing companies affect market share positively. Mansoor, et al., (2012) contended that the ideal organizational structure is a recipe for superior performance. Qingmin, et al., (2012) study in Austria and China found that organizational structure influence performance directly and indirectly. Oyewobi, et al., (2013) study on the impact of organizational structure and strategies on construction organizations performance, found that organization structure had no direct impact on both financial and non-financial performance. According to Powell (2014) firms with good structural organization fit perform better than those without. The study by Jung and Kim, (2014) of the public organizations in the USA showed empirical evidence that organizational structure affects perceived organizational performance. This study operationalized organization structure both on structural characteristics and control mechanisms.

\section{Industry Environment}

According to De Waal (2004), various factors influence the degree in which organization exhibit performance. High performance organizations are those that maximizes on joint effect of the firm level characteristics. These factors include; organization structure, organization culture and the organization resources. Organization would be expected to ensure that there is proper combination of the various firm factors especially organization structure, organization culture and the organization resources. Studies have mainly focused on independent effect of organization resources, culture and structure on firm performance. Further research is required to determine the moderating role of Industry environment on the 
combined effect of organization structure, organization culture and the organization resources on organization performance.

Research questions:

(i) Is there Moderating effect of Industry Environment on combined Effect of Organization Structure, Culture and Resources on Performance of Large Manufacturing Firms?

Research hypothesis

(ii) Industry Environment has moderating effect on relationship of Structure, Culture, Resources and Performance of Large Manufacturing Firms

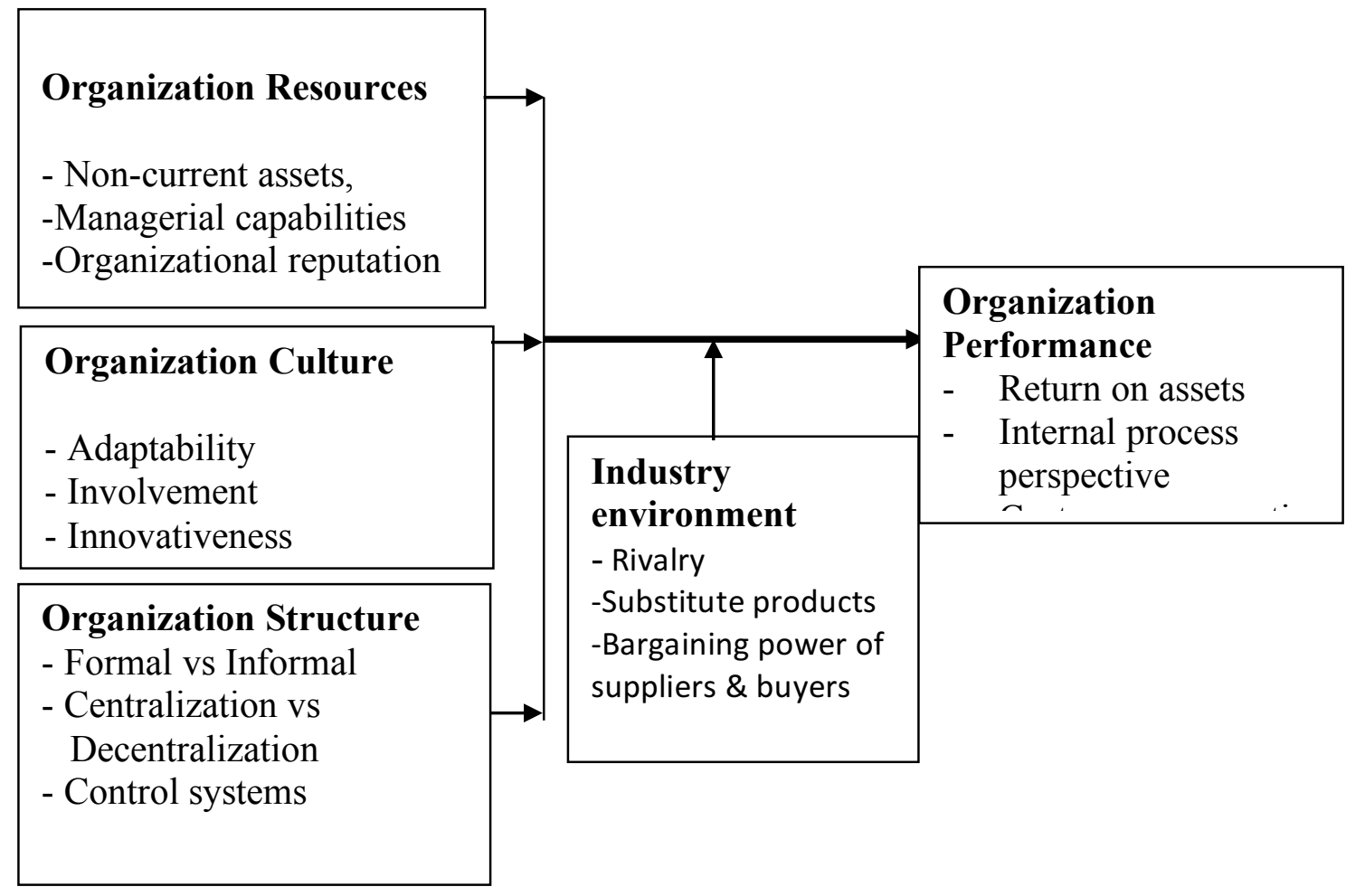

\section{Research Methodology}

This study was based on the positivist paradigm. The study was a cross-sectional survey to collect data at a particular time rather than over a period of time. The population of the study was all large manufacturing firms in Kenya (KAM 2016); there were 102 large manufacturing firms in Kenya. In determining the size of the firm, several different measures have been used and accepted as appropriate. They included sales turnover, capital employed, the value of output, asset size and employment level. The indicator of large manufacturing firms in Kenya is a firm with an annual sales turnover of an excess of KShs 400 million (Awino, 2007; Waweru, 2008, KAM 2016). Basing on the sales turnover out of 627 manufacturing firms in Kenya, there are 102 large manufacturing firms with over sales turnover of an excess of KShs 400 million (Awino, 2007; Waweru, 2008, KAM, 2016) and this formed the target population and the study used census survey. The study used both primary and secondary data; the primary data were collected using a questionnaire. The questionnaire was delivered to 102 Chief Executive Officers (CEOs) or equivalent and 94 responded. The CEO and other senior managers are key informant and are typically most familiar with and responsible for the firm's performance and its relationship with various 
organization variables. The questionnaire was divided into eight distinct sections, section one respondent profile, section two organization profile, section three industry environment, section four- organization performance (Customer perspective and Internal Processes), section five organization resources, section six organization structure section seven organization culture. The secondary data was on performance (ROA) from financial statements and the company yearly publications. Organization resources were measured based on Non-current assets, Managerial capabilities, Organizational reputation. Organization culture; Adaptability, Involvement, Innovativeness, organization structure; Formal vs Informal, Centralization vs Decentralization, Control systems. Industry environment; Rivalry, Substitute products, Bargaining power of suppliers and buyers.

Data were analyzed using Statistical Package for Social Sciences (SPSS) through a combination of both descriptive and inferential statistics. The F test of significance was performed to determine if the variables significantly contributed to the prediction of the dependent variable. Overall significance used F-test and p- values. When p-value $<0.05$, the null hypotheses were rejected, otherwise they were not rejected. To test individual significance, and $\mathrm{p}$-values were used using the same level of significance $(\alpha=0.05)$.

The data were subjected to reliability tests to check the consistency of the measurement set. Reliability was operationalized as internal consistency and established through computation of Cronbach's alpha coefficient. The Cronbach's alpha coefficient were $0.813,0.857,0.814,0.775$ for organization structure, organization culture, organization resources and Industry environment respectively. All the variables had Cronbach's alpha coefficient of more than 0.70 and therefore the data was reliable. Content validity was tested through expert judgment comprising of managers in manufacturing firms and scholars in strategic management. The mathematical model for Multiple regression analysis;

$\mathrm{IP}=\beta 0+\beta 1 \mathrm{OR}+\beta 2 \mathrm{OC}+\beta 3 \mathrm{OS}+\beta 4 \mathrm{IE}+\varepsilon$

Dependent variable-Performance(IP), Organizational resources (OR) OC-Organization culture

OS- Organization structure(OS), IE -Industry environment, where $\beta_{0}$ is the constant and $\beta_{1}$ is the coefficient (slope or gradient) and $\varepsilon$ is the error term.

\section{Analysis and Results}

\section{Descriptive Statistics of the Study Variables}

According to Table 4.1, Organization structure had the highest mean of 4.5071, Organization culture had the lowest mean of 4.0480 while organization resources had the lowest standard deviation of 0.49546 .

Table 4.1 Descriptive Statistics of The Study Variables

\begin{tabular}{|l|l|l|l|}
\hline Variable & & Mean & Std. Deviation \\
\hline Organization structure & 94 & 4.5071 & .58909 \\
\hline Organization culture & 94 & 4.0480 & .50541 \\
\hline Organization resources & 94 & 4.0541 & .49546 \\
\hline Industry environment & 94 & 4.4005 & .57138 \\
\hline
\end{tabular}

\section{Correlations of Independent Variables}

Table 4.2 indicates that organization culture has positively moderately weak $(0.416)$ relationship with organization structure and the correlation is statistically significant. Industry environment and organization structure have weak positive correlation $(0.183)$ which is not statistically significant. Industry environment has negative correlation $(-0.98)$ 
with organization culture. Organization resources has negative correlation $(-0.088)$ with industry environment which is not statistically significant.

Table 4.2 Correlation Matrix

\begin{tabular}{|l|l|c|c|c|c|}
\hline Variable & $\begin{array}{c}\text { Organization } \\
\text { Structure }\end{array}$ & $\begin{array}{c}\text { Organization } \\
\text { Culture }\end{array}$ & $\begin{array}{c}\text { Industry } \\
\text { Environment }\end{array}$ & $\begin{array}{c}\text { Organization } \\
\text { Resources }\end{array}$ \\
\hline $\begin{array}{l}\text { Organization } \\
\text { Structure }\end{array}$ & $\begin{array}{l}\text { Pearson } \\
\text { correlation }\end{array}$ & 1 & & & \\
\cline { 2 - 6 } & Sig. (2-tailed) & & & & \\
\hline \multirow{2}{*}{$\begin{array}{l}\text { Organization } \\
\text { Culture }\end{array}$} & $\begin{array}{l}\text { Pearson } \\
\text { Correlation }\end{array}$ & $.416^{* *}$ & 1 & & \\
\cline { 2 - 6 } & Sig. (2-tailed) & .000 & & & \\
\hline $\begin{array}{l}\text { Industry } \\
\text { Environment }\end{array}$ & $\begin{array}{l}\text { Pearson } \\
\text { Correlation }\end{array}$ & .183 & -.098 & 1 & \\
\hline & Sig. (2-tailed) & .077 & .346 & & 1 \\
\hline $\begin{array}{l}\text { Organization } \\
\text { Resources }\end{array}$ & $\begin{array}{l}\text { Pearson } \\
\text { Correlation }\end{array}$ & $.311^{* *}$ & $.411^{* *}$ & -.088 & \\
\cline { 2 - 7 } & Sig. (2-tailed) & .002 & .000 & .401 & \\
\hline
\end{tabular}

Firm level factors and Performance

The performance was measured based on Return on assets, customer perspective and Internal processes.

\section{Organizational Structure, Culture and Resources on Return on Assets as Moderated by Industry Environment}

Table 4.3 indicates that the effect of organizational structure, culture and resources on return on assets as moderated by industry environment. The results indicate that coefficient of determination increased by 0.048 from 0.142 and the $\mathrm{F}$ change is statistically significant. The overall test of significance after moderating effect is 5.153 which is statistically significant. When the performance measures was based on internal processes, customer perspective the F change was statistically significant.

Table 4.3 Model Summary

\begin{tabular}{|c|c|c|c|c|c|c|c|c|c|}
\hline \multirow[t]{2}{*}{ Model } & \multirow[t]{2}{*}{$\mathrm{R}$} & \multirow[t]{2}{*}{ R Square } & \multirow{2}{*}{$\begin{array}{l}\text { Adjusted } \\
\text { R Square }\end{array}$} & \multirow{2}{*}{$\begin{array}{l}\text { Std. Error } \\
\text { of the } \\
\text { Estimate }\end{array}$} & \multicolumn{5}{|c|}{ Change Statistics } \\
\hline & & & & & $\begin{array}{l}\text { R Square } \\
\text { Change }\end{array}$ & $\begin{array}{l}\text { F } \\
\text { Change }\end{array}$ & df1 & df2 & $\begin{array}{l}\text { Sig. F } \\
\text { Change }\end{array}$ \\
\hline 1 & $.377^{\mathrm{a}}$ & .142 & .113 & .06689 & .142 & 4.920 & 3 & 89 & .003 \\
\hline 2 & $.436^{\mathrm{b}}$ & .190 & .153 & .06538 & .048 & 5.162 & 1 & 88 & .026 \\
\hline
\end{tabular}

a. Predictors: (Constant), Organization Resources, Organization Structure, Organization Culture

b. Predictors: (Constant), Organization Resources, Organization Structure, Organization Culture, Industry Environment

\begin{tabular}{|c|c|c|c|c|c|c|}
\hline \multicolumn{7}{|c|}{ ANOVA $^{\mathrm{a}}$} \\
\hline Model & & Sum of Squares & $\mathrm{df}$ & Mean & $\mathrm{F}$ & Sig. \\
\hline \multirow{3}{*}{1} & Regression & .066 & 3 & .022 & 4.920 & $.003^{\mathrm{b}}$ \\
\hline & Residual & .398 & 89 & .004 & & \\
\hline & Total & .464 & 92 & & & \\
\hline \multirow{3}{*}{2} & Regression & .088 & 4 & .022 & 5.153 & $.001^{\mathrm{c}}$ \\
\hline & Residual & .376 & 88 & .004 & & \\
\hline & Total & .464 & 92 & & & \\
\hline
\end{tabular}

a. Dependent Variable: ROA

b. Predictors: (Constant), Organization Resources, Organization Structure, Organization Culture 
c. Predictors: (Constant), Organization Resources, Organization Structure, Organization Culture, Industry Environment

\section{Organizational Structure, Culture and Resources on Internal Processes as Moderated by Industry Environment}

Table 4.4 indicates the effect of organizational structure, culture and resources on internal processes as moderated by industry environment. The results indicate that coefficient of determination increased by 0.061 from 0.320 to 0.380 which imply that industry environment had the intervening effect. The $\mathrm{F}$ change is statistically significant. On moderating intervening effect by the industry environment the organization structure, culture and resources explains 38 percent of internal processes variation.

Table 4.4 Model Summary

\begin{tabular}{|c|c|c|c|c|c|c|c|c|c|}
\hline \multirow[t]{2}{*}{ Model } & \multirow[t]{2}{*}{$\mathrm{R}$} & \multirow{2}{*}{$\begin{array}{l}\mathrm{R} \\
\text { Square }\end{array}$} & \multirow{2}{*}{$\begin{array}{l}\text { Adjusted } \\
\text { R Square }\end{array}$} & \multirow{2}{*}{$\begin{array}{l}\text { Std. Error } \\
\text { of the } \\
\text { Estimate }\end{array}$} & \multicolumn{5}{|c|}{ Change Statistics } \\
\hline & & & & & $\begin{array}{l}\text { R Square } \\
\text { Change }\end{array}$ & $\begin{array}{l}\mathrm{F} \\
\text { Change }\end{array}$ & df1 & df2 & $\begin{array}{l}\text { Sig. F } \\
\text { Change }\end{array}$ \\
\hline $\begin{array}{l}1 \\
2 \\
\end{array}$ & $\begin{array}{l}.565^{\mathrm{a}} \\
.617^{\mathrm{b}}\end{array}$ & $\begin{array}{l}.320 \\
.380 \\
\end{array}$ & $\begin{array}{l}.297 \\
.352 \\
\end{array}$ & $\begin{array}{l}.41380 \\
.39714 \\
\end{array}$ & $\begin{array}{l}.320 \\
.061 \\
\end{array}$ & $\begin{array}{l}14.098 \\
8.709 \\
\end{array}$ & $\begin{array}{l}3 \\
1 \\
\end{array}$ & $\begin{array}{l}90 \\
89 \\
\end{array}$ & $\begin{array}{l}.000 \\
.004 \\
\end{array}$ \\
\hline
\end{tabular}

a. Predictors: (Constant), Organization Resources, Organization Structure, Organization Culture

b. Predictors: (Constant), Organization Resources, Organization Structure, Organization Culture, Industry

Environment

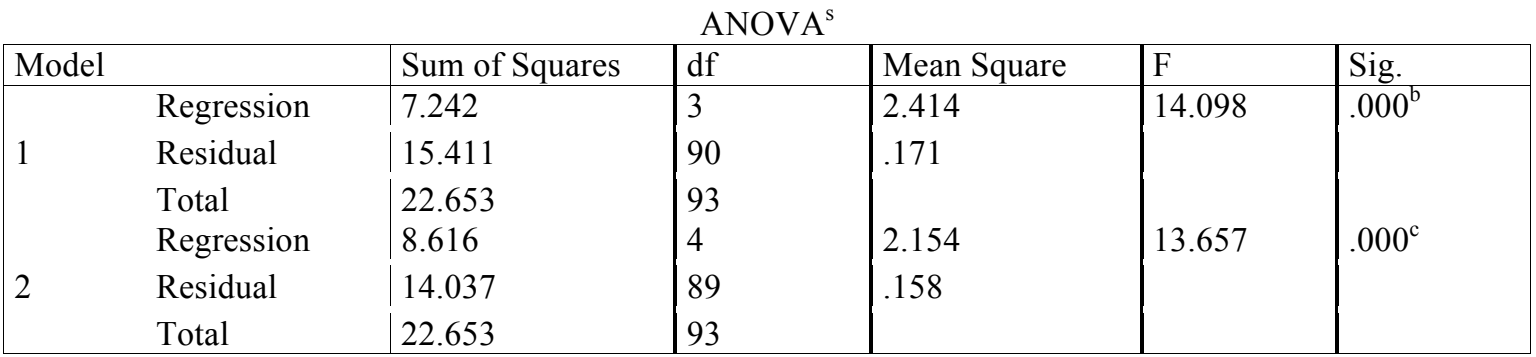

a. Dependent Variable: Internal Processes

b. Predictors: (Constant), Organization Resources, Organization Structure, Organization Culture

c. Predictors: (Constant), Organization Resources, Organization Structure, Organization Culture, Industry

Environment

\section{Organizational Structure, Culture and Resources on Customer Perspective as Moderated by Industry Environment}

Table 4.5 indicates the effect of organizational structure, culture and resources on customer perspective as moderated by industry environment. The results indicate that coefficient of determination increased by 0.059 from 0.115 to 0.174 which imply that industry environment had the intervening effect. The $\mathrm{F}$ change is statistically significant. On moderation by the industry environment the organization structure, culture and resources explains 17.4 percent of customer perspective variation.

Table 4.5 Model Summary

\begin{tabular}{|c|c|c|c|c|c|c|c|c|c|}
\hline \multirow[t]{2}{*}{ Model } & \multirow[t]{2}{*}{$\mathrm{R}$} & \multirow{2}{*}{$\begin{array}{c}\mathrm{R} \\
\text { Square }\end{array}$} & \multirow{2}{*}{$\begin{array}{l}\text { Adjusted } \\
\text { R Square }\end{array}$} & \multirow{2}{*}{$\begin{array}{l}\text { Std. Error } \\
\text { of the } \\
\text { Estimate }\end{array}$} & \multicolumn{5}{|c|}{ Change Statistics } \\
\hline & & & & & $\begin{array}{l}\text { R Square } \\
\text { Change }\end{array}$ & $\begin{array}{c}\mathrm{F} \\
\text { Change }\end{array}$ & df1 & $\mathrm{df} 2$ & $\begin{array}{c}\text { Sig. F } \\
\text { Change }\end{array}$ \\
\hline 1 & $.339^{\mathrm{a}}$ & .115 & .085 & .70182 & .115 & 3.855 & 3 & 89 & .012 \\
\hline 2 & $.417^{\mathrm{b}}$ & .174 & .136 & .68200 & .059 & 6.247 & 1 & 88 & .014 \\
\hline
\end{tabular}

a. Predictors: (Constant), Organization Resources, Organization Structure, Organization Culture

b. Predictors: (Constant), Organization Resources, Organization Structure, Organization Culture, Industry

Environment 


\begin{tabular}{|c|c|c|c|c|c|c|}
\hline \multicolumn{7}{|c|}{ ANOVA $^{a}$} \\
\hline & & Sum of Squares & df & Mean Square & $\mathrm{F}$ & Sig. \\
\hline \multirow{3}{*}{1} & Regression & 5.696 & 3 & 1.899 & 3.855 & $.012^{b}$ \\
\hline & Residual & 43.837 & 89 & .493 & \multirow{5}{*}{4.623} & \multirow{5}{*}{$.002^{\mathrm{c}}$} \\
\hline & Total & 49.532 & 92 & & & \\
\hline \multirow{3}{*}{2} & Regression & 8.601 & 4 & 2.150 & & \\
\hline & Residual & 40.931 & 88 & .465 & & \\
\hline & Total & 49.532 & 92 & & & \\
\hline
\end{tabular}

a. Dependent Variable: Customer Perspective

b. Predictors: (Constant), Organization Resources, Organization Structure, Organization Culture

c. Predictors: (Constant), Organization Resources, Organization Structure, Organization Culture, Industry Environment

\section{Discussion and Implications}

The results in Table 4.3, 4.4 and 4.5 indicates that industry environment has statistically significant moderating effect on relationship of organization resources, structure, culture and performance of manufacturing firms in Kenya. This was irrespective of measure of performance; return on assets, internal processes and customer perspective. The moderating effect of the industry environment is consistent with Porter (1985) about the relevance of industry environment to businesses. The results are in tandem with the Industrial Organizational Theory which emphasis about the importance of external factors influence to organizational performance (Karabag, 2008; Ruefli \& Wiggins, 2003). The results are also consistent with Mansoor et al (2012) who assert that for an organization structure to achieve superior performance there must be adequate attention to match the prevailing environment dynamism. Results are consistent with Ansoff and McDonnell (1990) which emphasizes on importance of external environment. Peteraf (1993) however challenged the importance of industry environment in influencing organization performance. The results are inconsistent with Resources Based Theory which emphasizes more on importance of firm resources as a key variable to determine performance (Barney, 1995). It is very clear from the foregoing there is complementarity of the two theories Industrial Organization Theory and Resources Based Theory in driving firm performance.

The finding of the study has some implications to the theories that formed the theoretical foundation. The results of study indicated that organization resources influence the organizational performance and therefore support the Resource Based Theory. The dynamic capabilities theory is supported by the study because it argues that beyond a firm having resources it is imperative to determine how to maximize on their utilization. The study results showed that industry environment had a moderating role on relationship between firm level factors and performance. This therefore supports the relevance of industrial organization theory about the role of external factors such as the industry environment. The study results indicate the applicability of contingency theory that organization performance is product of combination of different firm level factors. The results of this study have implications to management and practice. The manager should constantly scan the industry environment since it statistically significantly moderates the relationship between organization resources, structure, culture and performance. Additionally, the firm internal elements; resources, structure and culture are critical determinants of firm performance. The management should align and co-align appropriately the three elements to realize the firm superior performance. 


\section{Conclusion}

This study has successfully explored the moderating effect of Industry environment on the relationship of organization resources, culture and structure, and performance of large manufacturing firms in Kenya. The researcher concludes that industry environment statistically significantly moderate relationship of organization resources, culture and structure and performance of large manufacturing firms in Kenya. The results indicate that moderation effect of industry environment was significant using three different measures of performance; Return on assets, internal processes and Customer perspective.

\section{Limitations and Directions for Future Research}

The study was based on cross-sectional survey design and, therefore results based on data at a particular point in time. The study was limited in that change in various variables of the study was not monitored or observed over time as would be the case with longitudinal studies. The study was limited to large manufacturing firms, registered with the Kenya Association of Manufacturers (KAM). Therefore, manufacturers that are non-members of the KAM are not included in the target population. A longitudinal research study and/or making use of the qualitative approach can be considered. The hypothesis of the study can be tested at the industry level and find out whether the results would be similar as compared to results where the context is the entire manufacturing sector. The dilemma about whether internal or external factors influence performance more can be explored.

\section{References}

Akinyele, S. T. (2011). The significance of strategic marketing to enterprise performance: An empirical analysis of Nigerian oil and gas industry. Global Journal of Management andBusiness Research,10(6), 60-77.

Alimin Ismadi Ismail, Raduan Che Rose, Jegak Uli and Haslinda Abdullah (2012). The relationship between organizational resources, capabilities, systems and competitive advantage. Asian Academy of Management Journal, 17, 1, 151-173.

Awino, Z. B. (2007). Effect of selected strategy variables on corporate performance in the supply chain management of large private manufacturing firms in Kenya. Published Ph.D. Thesis, University of Nairobi, Kenya.

Barney, J. B. (1991). Firm resources and sustained competitive advantage.Journal of Management. 17(1), 99-120.

Barney, J. B. (1995). Looking inside for competitive advantage. Academy of Management Executive, 9(4), 49-61.

Barney, J. B. (2001b). Resource-based theories of competitive advantage: A ten-year retrospective on the resource-based view. Journal of Management, 27, 643-650.

Carmeli, A., \& Tishler, A. (2004). Resources, capabilities, and performance of industrial firms: A multivariate analysis. Management and Decision Economics, 25, 299-315.

Chan Su Jung \& Seok Eun Kim (2014) Structure and Perceived Performance in Public Organizations. Public Management Review, 16(5), 620-642

C. J. Chen \& J. W. Huang (2006), "How Organizational Climate and Structure Affect Knowledge Management, The Social Interaction Perspective," International Journal of Information Management, 27(2), 104- 118.

Chandler, A. D. (1962). Strategy and structure: Chapters in the history of the American industrial enterprise. Cambridge, MA: MIT Press.

Chen, Y. (2010). The continuing debate on firm performance: A multilevel approach to the IT sectors of Taiwan and South Korea. Journal of Business Research, 63, 471-478. 
Denison, D. R. (1990). Corporate culture and organizational effectiveness. New York, NY: Wiley

Ekpu, R. (2004). Associated gas utilization, Nigeria's Oil And Gas, 3(8), 17-18.

Galbreath, J., \& Galvin, P. (2008). Firm factors, industry structure, and performance variation: New empirical evidence to a classical debate. Journal of Business Research, 61, 109-117.

Grant, R. M. (1991). The resource-based theory of competitive advantage: Implications for strategy formulation, California Management Review, Spring, pp. 119-145.

Grewal, R., \& Tansuhaj, P. (2001). Building organizational capabilities for managing the economic crisis: The role of market orientation and strategic management. Journal of Marketing, 65, 67-80.

Hartwell, C. A, A \& A Kinicki 2011. Organization culture and Organization Effectiveness. A metanalytical investigation of the Competing values framework, theoretical suppositions. Journal of Applied Psychology, 96(4). 677-94

Hoopes DG, Madsen TL, \& Walker G. (2003). Guest editors' introduction to the special issue: Why is there a resource-based view? Toward a theory of competitive heterogeneity. Strategic Management Journal, October Special Issue 24: 889-902.

Johnson, G., Scholes, K., \& Whittngton, R. (2002). Exploringcorporate strategy. Prentice Hall: London.

Karabag, S. F., and Berggren, C. (2013). Antecedents of firm performance in the emerging economies business group, strategy, industry structure, and state support Linkoping University.

Kenya Industrial Research and Development Institute (2016).

Kenya National Bureau of Statistics. (2017).

King, A. W. (2007). Disentangling interfirm and intrafirm causal ambiguity: A conceptual model of causal ambiguity and sustainable competitive advantage. Academy of Management Review, 32(1), 156-178.

Kotter, J. (2012). Corporate culture and performance. New York, NY: Free Press

Mansoor, N., Aslam, H. D., Barbu, C. M., Capusneanu, S., \& Lodhi, M. A. (2012). Organizational culture as a determinant of organizational performance, uncovering essential facets of organic and mechanistic culture. American Journal of Scientific Research, 55, 48-55.

Morgan, N. A., Kaleka, A., \& Katsikeas, C. S. (2004). Antecedents of export venture performance: A theoretical model and empirical assessment. Journal of Marketing, 68, 90-108

Miller, S. R., \& Ross, A. D. (2003). An exploratory analysis of resource utilization across organizational units: Understanding the resource-based view. International Journal of Operations \& Production Management, 23(9), 1062-1083.

Eisend, M., Evanschitzky, H., \& Gilliland, D. I. (2016). The influence of organizational and national culture on new product performance. Journal of Product Innovation Management, 33(3), 260-276.

Newbert, S. L. (2007). Empirical research on the resource-based view of the firm: An assessment and suggestions for future research. Strategic Management Journal, $28(2), 121-146$.

Ogolla, K. O. (2012). Organizational configuration, stage of development and performance of commercial banks in Kenya. Unpublished Ph.D. thesis, University of Nairobi, Kenya. 
Oyewobi, A. O., Windapo, K. S., \& Rotimi, J. O. (2013). Impact of organizational structure and strategies on construction organizations performance.University of Cape Town, South Africa and Auckland University of Technology, New Zealand.

Peteraf, M. A. (1993). The cornerstones of competitive advantage: A resource-based view. Strategic Management Journal, 14(3), 179-191.

Porter, M. E. (1985). Competitive advantage, Free Press: New York.

Powell T. C (2014). Strategic Management and the Person, Strategic Organization. 12(3) 200-2007. Sage Publication.

Priem, R. L., \& Butler, J. E. (2001a). Is the resource-based "view" a useful perspective for strategic management research? Academy of Management Review, 26, 22- 40.

Priem, R. L., \& Butler, J. E. (2001b). Tautology in the resource-based view and the implications of externally determined resource value: Further comment. Academy of Management Review, 26, 57-66.

Qingmin, K., Helmut, N., \& Juergen, D. (2012). Managing beyond the factory walls: Effects of four types of strategic integration on manufacturing plant performance. Journal of Operations Management, 24, 148-164.

Romualdas G., \& Vida V. (2006). Journal of Business Economics and Management. VII, $4,201-211$

Schein, E. H. (2009). Organization psychology. Prentice Hall.

Sirmon, D. G., Hitt, M. A., \& Ireland, R. D. (2007). Managing firm resources in dynamic environments to create value: Looking inside the black box. Academy of Management Review, 32(1), 273-292.

T. Russell Crook, David J. Ketchen Jr., James G. Combs, \& Samuel Todd. (2008). Strategic Resources and Performance: A Meta-Analysis? Strategic Management Journal. 29: 1141-1154

Tuan, P. N., \& Takahashi, Y. (2012). Resource, organizational capabilities, and performance: Some empirical evidence from Vietnams supporting industries Hiroshima University.

Waweru, M. A. (2008). Competitive strategy implementation and its effect on performance in large private sector firms in Kenya. Unpublished Ph.D. thesis, University of Nairobi, Kenya.

Wernerfelt, B. (1995). The resource-based view of the firm: Ten years after. Strategic Management Journal, 16(3), 171-174.

Yin-His, L. (2012). Managerial capabilities, organizational culture and organizational performance: The resource-based perspective in Chinese lodging industry. The Journal of International Management Studies, 7(1).

Zheng, W., Yang, B., \& Mclean, G. N. (2010). Linking organizational culture, strategy and organizational effectiveness, the Mediating role of knowledge management. Journal of Business Research, 63,763-771. 